\title{
PENGARUH PENGGUNAAN MEDIA VIDEO TERHADAP PEMAHAMAN KONSEP DITINJAU DARI PENGETAHUAN AWAL SISWA
}

\author{
Ita Mafruchah $^{1}$, Mustaji ${ }^{2}$, Suryaman $^{3}$ \\ Universitas PGRI Adi Buana Surabaya ${ }^{1,3}$ \\ Universitas Negeri Surabaya ${ }^{2}$ \\ itamafruchah@gmail.com ${ }^{1}$ \\ mustaji_2005@yahoo.com² \\ suryaman_2005@yahoo.com ${ }^{3}$
}

\begin{abstract}
Abstrak
Tujuan penelitian ini adalah (1) mengetahui perbedaan pemahaman konsep siswa yang diajar menggunakan media video dengan media gambar, (2)mengetahui perbedaan pemahaman konsep siswa yang memiliki pengetahuan awal rendah dan tinggi, dan (3) mengetahui interaksi antara pembelajaran menggunakan media video dan pengetahuan awal terhadap pemahaman konsep. Populasi dalam penelitian ini adalah siswa kelas VIII MTs Negeri 2 dan MTs Negeri 4 Kota Surabaya.sampelnya berjumlah 146 siswa berasal dari dua sekolah. Data diperoleh dengan cara pretest dan postest diolah dengan menggunakan teknik analisis varian 2 jalur. Hasil penelitian menunjukkan nilai signifikansi media sebesar $0.002<0.05$ dengan Fhitung $=10.422$, pengetahuan awal sebesar $0.000<0.05$ dengan Fhitung 42.139, sedangkan nilai signifikansi media dan pengetahuan awal diperoleh $0.009<0.05$ dengan Fhitung =7.099. Sehingga disimpulkan bahwa (1) terdapat perbedaan pemahaman konsep siswa yang diajar menggunakan media video dengan media gambar, (2) terdapat perbedaan pemahaman konsep siswa yang memiliki pengetahuan awal rendah dan pengetahuan tinggi, dan (3) terdapat interaksi antara pembelajaran menggunakan media video dan pengetahuan awal terhadap pemahaman konsep.
\end{abstract}

Kata Kunci: Media video, pengetahuan awal, pemahaman konsep.

\begin{abstract}
This research was aimed at describing (1) to know the difference in concept understanding of between students who were taught by using video and the ones who learned from pictures as media, (2) to know the difference in concept understanding between students who had low and high initial knowledge, and (3) to know the interaction between learning using video as media and initial knowledge on concept understanding. . The population in this study were eighth grade students of MTsN 2 Surabaya and MTsN 4 Surabaya. The sample consisted of 146 students originating from these two schools. The data obtained by pretest and posttest were processed by using analysis technique of 2-ways variance. The results of study showed a significance value of media of $0.002<0.05$ with Fcalculation $=10.422$, initial knowledge of $0.000<0.05$ with Fcalculation of 42.139, while significance value of media and initial knowledge were obtained $0.009<0.05$ with Fcalculation $=7.099$. So, it was concluded that (1) there was difference between concept understanding of students who were taught by using video media and image media, (2) there was difference between concept understanding of students who had low and high initial knowledge, and (3) there was an interaction between learning using video media and initial knowledge on concept understanding.
\end{abstract}

Keywords: video media, initial knowledge, and concept understanding. 


\section{PENDAHULUAN}

Pendidikan adalah kunci utama dalam pembangunan suatu Negara, apabila suatu Negara pendidikannya baik maka kemungkinan bisa dipastikan Negara itu maju oleh karena itu sumber daya manusia harus selalu ditingkatkan sesuai dengan perkembangan jaman. Pada jaman yang semakin modern senantiasa mempengaruhi pola pikir manusia untuk selalu berperan aktif mengikuti perkembangan tersebut agar mampu bertahan dan mengembangkan pola kehidupan. Era globalisasi dan komputerisasi merupakan wujud nyata dari perkembangan yang terus terjadi. Demikian juga aplikasi multimedia yang semakin dikembangkan untuk mengubah cara manusia untuk berinteraksi dengan komputer melalui unsur teks, gambar, audio serta animasi dan visual dalam satu aplikasi.

Kemudahan aplikasi komputer yang terus di kembangkan sehingga lebih mendekati dengan kebutuhan manusia telah turut serta mempengaruhi penggunaan komputer sebagai alat bantu pembelajaran manusia. Multimedia pembelajaran berbasis video yang semakin banyak dan berkembang saat ini memberikan pilihan bagi pengguna untuk memilih multimedia mana yang tepat untuk membangun sebuah aplikasi berbasis video.

Menurut Woolfitt [1], video didefinisikan di sini sebagai konten yang direkam secara digital yang memiliki suara dan gerakan yang dapat disimpan atau dikirim secara langsung, dan dapat dialirkan ke berbagai perangkat. Mungkin atau mungkin tidak membuat dosen terlihat dan dapat menyertakan film animasi, atau demonstrasi. Menggunakan materi audio-visual di ruang kelas bukanlah hal yang baru. Pendidik telah mengakui kekuatan materi audio-visual untuk menangkap perhatian peserta didik, meningkatkan motivasi mereka dan meningkatkan pengalaman belajar mereka. Teknologi pengiriman juga telah maju, dari strip film ke televisi kabel, ke fleksibilitas VCR, DVD, dan laser. Akhirnya, dengan munculnya teknologi digital, bidang ini berkembang menjadi potensi adaptasi yang lebih baru dan lebih besar dalam tampilan.

Temuan survei paling signifikan yang mendukung nilai alat multimedia ini adalah hubungan langsung antara frekuensi penggunaan dan persepsi prestasi dan motivasi siswa. Hal ini mengacu pada rujukan Cruse [2] Di antara pengguna yang sering (guru yang melaporkan menggunakan TV atau video selama dua jam atau lebih per minggu), dua pertiga menemukan bahwa siswa belajar lebih banyak ketika TV atau video digunakan, dan hampir $70 \%$ menemukan bahwa motivasi siswa meningkat. Lebih dari separuh pengguna yang sering juga menemukan bahwa siswa menggunakan kosakata baru sebagai hasil dari penggunaan video. Penggunaan video untuk praktik di kelas meliputi: memperkuat bahan bacaan dan perkuliahan, memfasilitasi pengembangan basis pengetahuan umum di antara siswa, meningkatkan pemahaman dan diskusi siswa, menyediakan akomodasi yang lebih besar dari gaya belajar yang beragam, meningkatkan motivasi dan antusiasme siswa, dan mempromosikan guru efektivitas.

Matematika adalah mata pelajaran yang istimewa apabila peserta didik mampu dan bisa menyelesaikan semua permasalahan yang ada, tetapi menurut Irawati [3] banyak peserta didik yang menjadikan pelajaran matematika sebagai momok yang menakutkan, walaupun menakutkan peserta didik mau tidak mau harus mempelajarinya mulai dari sekolah dasar sampai dengan tingkat atas. Guru matematika banyak yang mengeluh bagaimana caranya supaya peserta didik bisa mendapat nilai baik saat ujian, bagaimana peserta didik bisa cepat faham dalam 
belajar dan bagaimana peserta didik cepat memahami apabila di terangkan oleh sebab itu dibutuhkan media pembelajaran video dimana peserta didik merasa senang pada saat pembelajaran seperti yang dikemukakan oleh Arsyad [4]

Sebagai penunjang kegiatan pembelajaran di tingkat Madrasah Tsanawiyah atau setingkat SMP penting sekali adanya media video. Menurut Susilana [5] hal ini dikarenakan media video merupakan salah satu media penyampaian pembelajaran yang dapat meningkatkan nilai pembelajaran bagi anak karena anak sebelum dijelaskan atau diterangkan melihat media yang berwarna warni, tampilannya menarik tanpa disadari menimbulkan perasaan senang, tingkat kesenangan peserta didik tersebut dapat merubah pemikiran peserta didik yang biasanya melihat judul saja peserta didik sudah berpikiran susah mungkin dengan adanya media video, penyajian yang dapat membantu pemahaman peserta didik dari hal yang abstrak ke konkrit. Apalagi menghadirkan benda asli disekeliling peserta didik akan merubah pikiran dari susah menjadi mudah. Sehingga sangat dibutuhkan adanya perangkat yang mampu menarik minat belajar serta meningkatkan nilai kecerdasan anak. Salah satu cara yang dapat digunakan untuk menarik minat belajar terutama untuk kalangan siswa kelas VIII MTs materi pelajaran Matematika yaitu dengan menyampaikan pelajaran yang sudah diaplikasikan ke dalam media video.

\section{METODE}

Desain penelitian quasi-eksperimental digunakan dalam peneitian ini sesuai rujukan Sugiyono [5]. Sebanyak 146 siswa kelas VIII dari dua sekolah, yaitu MTsN 2 Surabaya dan MTsN 4 Surabaya berpartisipasi dalam penelitian ini. Dua kelompok ditugaskan sebagai kelompok eksperimen $(n=73)$ dan sebagai kelompok kontrol $(\mathrm{n}=73)$ tanpa proses pemilihan acak karena administrasi sekolah tidak mengizinkan adanya perubahan dalam kelompok-kelompok ini untuk penelitian. Semua siswa kelas delapan telah ditempatkan di kelas heterogen. Matematika dipilih sebagai subjek untuk dipelajari. Semua kelompok menyelesaikan pretest dan posttest. Untuk kelompok eksperimen, pelajaran dirancang menggunakan video sebagai alat teknologi, sedangkan pelajaran untuk kelompok kontrol diajarkan menggunakan metode pengajaran tradisional dengan tidak ada teknologi yang digunakan. Data yang diperoleh dengan pretest dan posttest diolah dengan menggunakan analisis varian (Anava) 2 arah.

\section{HASIL DAN PEMBAHASAN}

Penelitian yang telah dilakukan mendapatkan hasil data dari pretest dan posttest kemampuan pemahaman konsep materi lingkaran. Kemudian di analisis dengan bantuan SPSS versi 22 dari kelas eksperimen dan kontrol. Hasil Analisis varians (Anava) 2 jalur dilakukan untuk menguji pengaruh antara pembelajaran media video dengan media gambar dan pengetahuan awal terhadap pemahaman konsep siswa seperti yang dikemukakan oleh Arikunto [6] 
TABEL 1 Data Variabel Faktor Penelitian.

\begin{tabular}{cccc}
\multicolumn{4}{c}{ Between-Subjects Factors } \\
\hline \hline & & Value Label & $\mathrm{N}$ \\
\hline Pengetahuan Awal & 1 & Rendah & 50 \\
& 2 & Tinggi & 96 \\
\multirow{2}{*}{ Media Pembelajaran } & 1 & Media Video & 72 \\
& 2 & Media Gambar & 74 \\
\hline \hline
\end{tabular}

Variabel faktor yang berupa pengetahuan awal yang terdiri dari rendah berjumlah 50 siswa dan tinggi berjumlah 96 siswa. Sedangkan variabel faktor yang berupa media pembelajaran yang terdiri dari video berjumlah 72 siswa dan gambar berjumlah 74 siswa. Hasil statistik deskriptif data penelitian seluruhnya ditunjukkan oleh tabel berikut:

TABEL 2 Hasil Statistik Deskriptif Data Penelitian Descriptive Statistics

Dependent Variable: Pemahaman Konsep

\begin{tabular}{clccc}
\hline \hline Pengetahuan Awal & Media Pembelajaran & Mean & Std. Deviation & $\mathrm{N}$ \\
\hline Rendah & Media Video & 77.44 & 7.012 & 25 \\
& Media Gambar & 76.80 & 5.888 & 25 \\
& Total & 77.12 & 6.416 & 50 \\
\hline \multirow{2}{*}{ Tinggi } & Media Video & 87.83 & 6.512 & 47 \\
& Media Gambar & 81.14 & 6.532 & 49 \\
& Total & 84.42 & 7.306 & 96 \\
\hline \multirow{2}{*}{ Total } & Media Video & 84.22 & 8.301 & 72 \\
& Media Gambar & 79.68 & 6.613 & 74 \\
& Total & 81.92 & 7.808 & 146 \\
\hline \hline
\end{tabular}

Tabel 2 menunjukkan nilai rata-rata pemahaman konsep siswa yang memiliki pengetahuan awal rendah memiliki rata-rata lebih kecil dari siswa yang memiliki pengetahuan awal tinggi. Demikian pula dengan nilai rata-rata pemahaman konsep siswa yang mengikuti pembelajaran dengan media video memiliki rata-rata lebih besar dari siswa yang mengikuti pembelajaran media gambar.

Selanjutnya hasil analisis varian dua jalur untuk menguji hipotesis penelitian ditunjukkan oleh Tabel 3 berikut ini.

TABEL 3 Hasil Analisis Varian Dua Jalur Tests of Between-Subjects Effects

\begin{tabular}{lrrrrr}
\hline \hline & Type III Sum of & & & & \\
Source & Squares & df & Mean Square & \multicolumn{1}{c}{ F } & Sig. \\
\hline Corrected Model & $2828.215^{\mathrm{a}}$ & 3 & 942.738 & 22.271 & .000 \\
Intercept & 858500.393 & 1 & 858500.393 & 20281.342 & .000 \\
Pengetahuan_awal & 1783.714 & 1 & 1783.714 & 42.139 & .000 \\
Media & 441.172 & 1 & 441.172 & 10.422 & .002 \\
Pengetahuan_awal * Media & 300.493 & 1 & 300.493 & 7.099 & .009 \\
Error & 6010.798 & 142 & 42.330 & & \\
Total & 988576.000 & 146 & & & \\
Corrected Total & 8839.014 & 145 & & & \\
\hline \hline
\end{tabular}

a. R Squared = .320 (Adjusted R Squared = .306) 
Dari Tabel 3 di atas menunjukkan nilai signifikansi untuk pengetahuan awal adalah $0.000<0.05$, berarti bahwa terdapat perbedaan pemahaman konsep siswa yang memiliki pengetahuan awal rendah dengan siswa yang memiliki pengetahuan awal tinggi. Dan nilai signifikansi untuk media pembelajaran adalah $0.002<0.005$, berarti bahwa terdapat perbedaan antara pemahaman konsep siswa yang menggunakan media video dengan media gambar. Sedangkan nilai signifikansi media video adalah $0.009<0.05$ artinya bahwa terdapat interaksi antara pembelajaran menggunakan video dan pengetahuan awal terhadap pemahaman konsep.

TABEL 4 Data Pemahaman Konsep Berdasarkan Pengetahuan Awal

\section{Pengetahuan Awal}

Dependent Variable: Pemahaman Konsep

\begin{tabular}{lrrrr} 
& & & \multicolumn{2}{c}{ 95\% Confidence Interval } \\
\cline { 4 - 5 } Pengetahuan Awal & Mean & Std. Error & Lower Bound & Upper Bound \\
\hline Rendah & 77.120 & .920 & 75.301 & 78.939 \\
Tinggi & 84.486 & .664 & 83.173 & 85.799 \\
\hline \hline
\end{tabular}

Tabel 4 di atas menunjukkan bahwa siswa yang mempunyai pengetahuan awal tinggi mendapatkan nilai pemahaman konsep yang lebih besar demikian pula untuk nilai batas bawah dan batas atas siswa yang mempunyai pengetahuan awal tinggi mendapat nilai pemahaman konsep yang lebih besar.

TABEL 5 Data Pemahaman Konsep Berdasarkan Media Pembelajaran

Media Pembelajaran

Dependent Variable: Pemahaman Konsep

\begin{tabular}{lrrrr}
\hline \hline & & & \multicolumn{2}{c}{$95 \%$ Confidence Interval } \\
\cline { 4 - 5 } Media Pembelajaran & Mean & Std. Error & Lower Bound & Upper Bound \\
\hline Media Video & 82.635 & .805 & 81.043 & 84.227 \\
Media Gambar & 78.971 & .800 & 77.391 & 80.552 \\
\hline \hline
\end{tabular}

Tabel 5 di atas menunjukkan bahwa siswa yang mengikuti media pembelajaran video mendapatkan nilai pemahaman konsep yang lebih besar. Demikian pula untuk nilai batas bawah dan batas atas, siswa yang mengikuti pembelajaran media video mendapatkan nilai pemahaman konsep yang lebih besar.

TABEL 6 Data Pemahaman Konsep berdasarkan Pengetahuan Awal dan Media Pembelajaran

\section{Pengetahuan Awal * Media Pembelajaran}

Dependent Variable: Pemahaman Konsep

\begin{tabular}{llrrrr}
\hline \hline \multirow{2}{*}{$\begin{array}{l}\text { Pengetahuan } \\
\text { Awal }\end{array}$} & Media & & & \multicolumn{2}{c}{ 95\% Confidence Interval } \\
\cline { 5 - 6 } Rendah & Pembelajaran & Mean & Std. Error & Lower Bound & Upper Bound \\
& Media Video & 77.440 & 1.301 & 74.868 & 80.012 \\
& Media Gambar & 76.800 & 1.301 & 74.228 & 79.372 \\
\hline Tinggi & Media Video & 87.830 & .949 & 85.954 & 89.706
\end{tabular}


Tabel 6 di atas menunjukkan bahwa siswa yang mengikuti media pembelajran video dan mempunyai pengetahuan awal tinggi memperoleh nilai pemahaman konsep yang lebih besar. Demikian pula untuk nilai batas bawah dan batas atas siswa yang mengikuti pembelajaran media video memperoleh nilai pemahaman konsep yang lebih besar.

Sedangkan untuk menilai apakah ada interaksi efek antar variabel, peneliti memberikan gambaran dengan diagram garis seperti yang ditunjukkan pada gambar berikut.

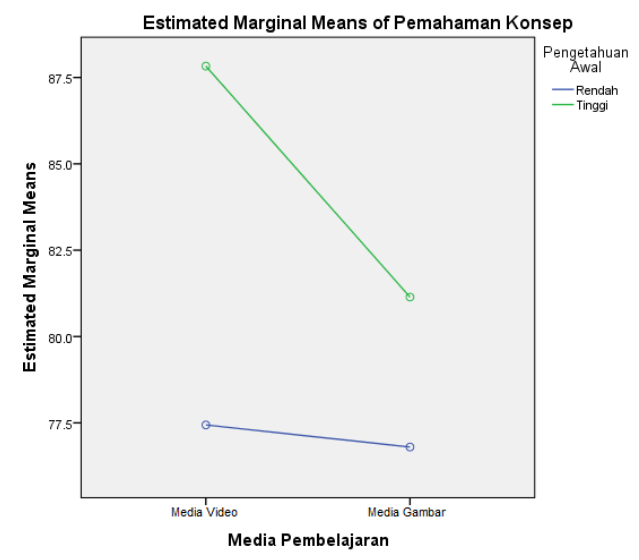

GAMBAR 1 Diagram garis Adanya Interaksi Antar Variabel

Gambar 1 adalah garis-garis yang menujukkan ketidak sejajaran, sehingga dicurigai ada efek interaksi antar variabel. Dapat disimpulkan bahwa terdapat interaksi antara media pembelajaran dan pengetahuan awal terhadap pemahaman konsep.

Hasil pengujian hipotesis pertama dengan berdasar pada hasil analisis (Fhitung) antara perlakuan media video diketahui sebesar 10.422, dengan taraf signifikansi (sign) 0.002 sesuai dengan kriteria pengujian hipotesis yang telah ditetapkan, hasil tersebut menunjukkan nilai $<0.05(5 \%)$. Hal ini berarti bahwa koefisien (Fhitung) adalah signifikan. Berdasarkan hasil tersebut dapat disimpulkan bahwa hipotesis kerja (Ha) diterima hipotesis nihil (Ho) ditolak sehingga dapat disimpulkan "Terdapat perbedaan hasil pemahaman konsep matematika antara kelompok siswa yang diberi perlakuan pembelajaran menggunakan media video dan kelompok siswa yang diberi perlakuan menggunakan media gambar pada siswa kelas VIII MTs Negeri 2 Kota Surabaya dan MTs Negeri 4 Kota Surabaya”.

Hasil pengujian hipotesis kedua dengan berdasar pada hasil analisis (Fhitung) antar "Pengetahuan Awal" diketahui sebesar 42.139, dengan taraf ngan hasil nilaisignifikan $(\mathrm{sig})=0.000$, sesuai dengan kriteria pengujian hipotesis yang telah ditetapkan, hasil tersebut diatas menunjukkan nilai > 0.05 (5\%). Hal ini berarti Koefisien (Fhitung)adalah signifikan. Berdasarkan hal tersebut dapat disimpulkan bahwa hipotesis kerja (Ha) diterima hipotesis nihil (Ho) ditolak sehingga dapat disimpulkan "terdapat perbedaan hasil pemahaman konsep matematika antara kelompok siswa yang memiliki pengetahuan awal rendah dan kelompok siswa yang 
memiliki pengetahuan awal tinggi pada siswa kelas VIII MTs Negeri 2 dan MTs Negeri 4 Kota Surabaya".

Hasil pengujian hipotesis ketiga dengan berdasar pada hasil analisis (Fhitung) antar perlakuan "Media" dan "Pengetahuan Awal" diketahui sebesar = 7.099, dengan taraf signifikansi (sign) $=0.009$, sesuai dengan kriteria pengujian hipotesis yang telah ditetapkan, hasil tersebut diatas menunjukkan nilai $>0.05$ (5\%) . Hal ini berarti bahwa koefisien (Fhitung) signifikan. Berdasarkan hasil tersebut dapat disimpulkan bahwa hipotesis kerja(Ha) diterima dan (Ho) ditolak sehingga dapat disimpulkan" Terdapat interaksi antara pembelajaran menggunakan media video dan pengetahuan awal terhadap pemahaman konsep matematika pada siswa kelas VIII MTs Negeri 2 Kota Surabaya dan MTs Negeri 4 Kota Surabaya".

Temuan ini bermanfaat untuk me pengetahuan bagi para guru tentang bagaimana menggunakan multimedia dalam pengajaran mereka. Temuan ini juga bermanfaat bagi siswa yang menghadapi kesulitan dalam matematika baik menemukan konsep, konstruksi dan bahasa matematika sulit untuk diikuti, atau tidak melihat nilai tambah yang matematika dapat bawa ke kolam pengetahuan mereka, dan dengan demikian kurang motivasi. Sekarang karena pilihan telah dibuat untuk mempelajari mengatasi masalah ini menggunakan video, pemahaman yang lebih dalam dari media ini diperlukan untuk secara efektif menerapkannya pada masalah yang dihadapi sebagaimana yang telah ditemukan oleh Millykoski [7].

Hasil ini konsisten dengan apa yang dikutip Widodo [8] bahwa video dapat berfungsi sebagai alat mediasi untuk refleksi kritis dan fokus. Selain itu, video memungkinkan seseorang untuk memahami konteks pengamatan ketika melihat data yang direkam. Sedemikian rupa, data rekaman video memungkinkan seseorang untuk mengingat apa yang dia amati, sehingga meningkatkan tingkat refleksivitas karena rekaman video dapat diputar berkali-kali. Hasilnya juga didukung oleh Eyyam dan Yaratan [9] yang mengindikasikan bahwa matematika Hasil posttest dari siswa yang diajar menggunakan teknologi secara signifikan lebih tinggi daripada hasil posttest dari kelompok yang diajari tanpa teknologi. Hasil penelitian menunjukkan bahwa siswa memiliki sikap positif terhadap penggunaan teknologi.Lebih jauh, kemampuan untuk belajar dari dan melalui multimedia seperti video tetap penting untuk berfungsi sebagai individu yang sepenuhnya melek, dan semua memprioritaskan literasi visual dan media sebagai salah satu keterampilan penting abad ke-21 seperti yang diungkapkan oleh Cruse [2] dan Brynjolfsson and Mcafee [10].

Studi yang mengeksplorasi keberhasilan siswa dengan menggunakan teknologi pendidikan dilakukan dengan menggunakan matematika sebagai subjek, dan itu bisa diulang dengan mata pelajaran sekolah lainnya. Temuan dalam penelitian ini dapat menjelaskan penggunaan teknologi pendidikan untuk mengajar matematika dalam sistem pendidikan serupa di seluruh dunia, dalam rangka mendorong administrator pendidikan untuk menerapkan penggunaan teknologi pendidikan dalam pelajaran matematika.

\section{KESIMPULAN}

Setelah melakukan penelitian dan pembahasan secara menyeluruh baik dari perlakuan pembelajaran (Media video vs Media gambar) dan pengetahuan awal 
yang dimiliki siswa (rendah dan tinggi), maka pada bagian ini penulis dapat menarik kesimpulan dari hasil-hasil yang didapat tersebut. Berikut kesimpulan yang dapat diambil yaitu (1) terdapat perbedaan hasil pemahaman konsep matematika antara kelompok siswa yang diberi perlakuan pembelajaran menggunakan media video dan kelompok siswa yang diberi perlakuan menggunakan media gambar pada siswa kelas VIII MTs Negeri 2 Kota Surabaya dan MTs Negeri 4 Kota Surabaya, (2) terdapat perbedaan hasil pemahaman konsen matematika antara kelompok siswa yang memiliki pengetahuan awal rendah dan kelompok siswa yang memiliki pengetahuan awal tinggi pada siswa kelas VIII MTs Negeri 2 Kota Surabaya dan MTs Negeri 4 Kota Surabaya, (3) terdapat interaksi antara pembelajaran menggunakan media video dan pengetahuan awal terhadap pemahaman konsep matematika pada siswa kelas VIII MTs Negeri 2 Kota Surabaya dan MTs Negeri 4 Kota Surabaya.

Berdasarkan kesimpulan diatas peneliti memberikan saran-saran yaitu: (1) pembelajaran media video dapat dijadikan sebagai alternatif media pembelajaran yang dapat meningkatkan kemampuan pemahaman konsep, oleh karena itu para guru matematika diharapkan dapat menerapkan media ini dalam pembelajaran matematika khususnya pada materi lingkaran kelas VIII, (2) guru hendaknya meningkatkan aktivitas siswa dalam pembelajaran sehingga dapat meningkatkan kemampuan pemahaman siswa dan pencapaian prestasi belajar siswa dapat lebih optimal, (3) perlunya penelitian lebih lanjut untuk materi dan kelas yang berbeda dan jika memungkinkan untuk mata pelajaran lain yang relevan.

\section{DAFTAR RUJUKAN}

[1] Woolfitt, Z. (2015) The Effective Use of Video in Higher Education. Lectoraat Teaching, Learning and Technology Inholland University of Applied Sciences.

[2] Cruse, E. (2007). Using Educational Video in the Classroom: Theory, Research and Practice.Retrieved from https://www.semanticscholar.org/paper/Using-Educational-Video-inthe-Classroom\%3A-Theory\%2C-Cruse/0655b4a1a63b15d2d457f103aa5745fa7847f211.

[3] Irawati, T.N. (2018). Analisis Kemampuan Berpikir Tingkat Tinggi Siswa SMP Dalam Menyelesaikan Soal Pemecahan Masalah Matematika Pada Materi Bilangan Bulat. Jurnal Gammath,3 (2), 1-7.

[4] Arsyad, A. (2013). Media Pembelajaran. Jakarta, Indonesia: Divisi Buku Perguruan Tinggi PT Raja Grafindo Persada.

[5] Sugiyono. (2014). Metode Penelitian Kuantitatif Kualitatif dan R\&D (20 ed.). Bandung: Alfabeta.

[6] Arikunto, S.(1998). Prosedur Penelitian: Suatu Pendekatan Praktik. Jakarta: Rineka Cipta.

[7] Myllykoski, T. (2016). Educational Videos and the Use of Tools in Mathematics Remedial Instruction. Unpublished Master of Science Thesis, Tampere University of Technology.

[8] Widodo, H. P. (2009). Key Issues in Teaching EFL/ESL Intensive Reading: A Videotaped Self-Observation Report. The Journal of Effective Teaching, 9 (3), 38-58.

[9] Eyyam, R. and Yaratan, H. S. (2014). Impact of Use of Technology in Mathematics Lessons on Student Achievement and Attitudes.SOCIAL BEHAVIOR AND PERSONALITY, 42(Suppl.), S31-S42.

[10] Brynjolfsson, E. and Mcafee, A. (2014) The Second Machine Age (1st ed.). New York: W.W. Norton \& Company. 